\title{
Genetic Variability, Heritability and Genetic Advance studies in Quantitataive Traits in Rice (Oryza sativa L.)
}

\author{
Sirigadi Rajesh*, K. Chaithanya, J. Sajeev, B. Jalandhar Ram and B. G. Suresh \\ Department of Genetic and Plant Breeding, Sam Higginbottom University of Agriculture, \\ Technology and Sciences, Prayagraj-(211007), Uttar Pradesh, India \\ *Corresponding author
}

Keywords

Rice (Oryza sativa L.), genetic variability, heritability and genetic advance

Article Info

Accepted:

18 July 2019

Available Online:

10 August 2019

\section{A B S T R A C T}

The present investigation carried out on 25 rice genotypes during Kharif-2018 at field experimentation centre of Genetics and Plant Breeding, Naini Agricultural Institute, SHUATS, Prayagaraj to assess genetic variability, heritability and genetic advance. Analysis of variance showed highly significant genetic variability for all the 25 rice genotypes for 13 quantitative characters studied indicating that significant at $1 \%$ and $5 \%$ genetic variability present in the material. High to moderate estimates of GCV and PCV were recorded for number of panicles per hill, number of spikelets per panicle, test weight, flag leaf length, days to $50 \%$ flowering, plant height, and grain yield per hill. High estimates of heritability coupled with high values of genetic advance as perecent mean was observe for characyers number of spikelets per panicle, days to $50 \%$ flowering, number of panicles per hill and test weight respectively suggesting there was preponderance of additive gene action for the experession of these characters. Hence selection of these traits were useful for further improvement in breeding programme.

\section{Introduction}

Rice (Oryza sativa L.) is a cultivated crop belonging to family Graminae, sub-family Bamboosoideae and tribe Oryzeae (sarla and Swamy, 2005). It is diploid with 12 chromosomes $(2 \mathrm{n}=24)$ (Garriset et al., 2005). Rice is cultivated as low as $3 \mathrm{~m}$ below sea level in Bhutan and Nepal khush and Virk, 2000). It is one of the major food crops all over the world and is the most widely consumed staple food for large part of the world's human population, especially in Asian region. It is the agricultural commodity which in production ranks third (741.5 million tons in 2014) worldwide after sugarcane and maize. However, in aspect of calories intake and nutrition, it is the most important grain which provides more than one fifth of the calories to human, worldwide (Smith, Bruce $\mathrm{D}$, 1998). Rice contains starch (75-80\%), water (12\% and protein (7\%) (Hossain et al., 2015). Also, in many countries of the world, rice is the source of animal feed (Muhammad 
et al., 2015). According to Economic survey 2017-2018 total production of rice in India is 110.2 million tons with gross area of 43.2 million hectares, whereas yield per hectare is $2550 \mathrm{~kg}$. Indian states like West Bengal contributes (15.1 million tons), U. P (12.9 million tons) and Punjab (11.0 million tons) in production of rice in India.

\section{Materials and Methods}

The experimental material comprised of 25 germplasm of rice (oryza sativa L.) grown in $\mathrm{RBD}$ at field experimentation centre of Genetics and Plant Breeding, Naini Agricultural Institute, SHUATS, Prayagraj, U. $\mathrm{P}$, India, during Rabi 2018. The recommended agronomic and plant protection measures were followed in order to raise a normal crop. Observations on 13 different quantitative characters viz., days to $50 \%$ flowering, days to maturity, plant height, flag leaf length, flag leaf width, number of tillers per hill, number of panicles per hill, panicle length, number of spikelets per panicle, biological yield, test weight, harvest index and grain yield per hill were recorded on 5 randomly selected plants for each replication of each genotype except for days to $50 \%$ flowering and days to maturity where data is recorded based on plot basis during various phenophase of the crop.

Mean values of 5 randomly selected plants of 3 replications for each genotype were averaged and expressed as the mean of the respective character and considered by RBD for each of the character separately as per standard statistical procedure given by (Panse and Sukhtame, 1978).

Heritability (h2) in the broad sense was calculated according to the formula given by (Allard, 1960) for all the characters. Phenotypic and genotypic coefficient of variation (PCV and GCV) were computed according to (Burton, 1952).

\section{Results and Discussion}

Analysis of variance shown that highly significant differences among the genotypes for all the traits as shown in Table 1. This indicates that there was an ample scope for selection of promising lines from the present gene pool for yield and its components. The presence of large amount of variability might due to diverse source of materials taken as well as environmental influence affecting the phenotypes.

On the basis of mean performance as shown in Table 2, the highest grain yield per hill was observed for the rice genotypes like MTU1075 (43.00g) followed by MTU-1121 (42.40g), MTU-1001 (40.50g) and IR-11N$187(40.20 \mathrm{~g})$ was found to be superior in grain yield.

In the present investigation as shown in Table 3. The studies on GCV and PCV indicated that the presence of high amount of variation and role of the environment on the expression of these traits. The magnitude of PCV was higher than GCV for all the characters which may due to higher degree of interaction of genotype with the environment (Senapathi and Kumar, 2015).

Among the 13 quantitative characters GCV ranged from harvest index $(4.31 \%)$ to number of panicles per hill $(31.11 \%)$. The GCV estimates would show that the genotypic variability was low (below 10\%) for harvest index $(4.31 \%)$, biological yield $(8.91 \%)$ and panicle length $(9.94 \%)$. Moderate $(10-20 \%)$ for flag leaf width $(10.98 \%)$, grain yield per hill (11.19\%), days to maturity (11.53\%), plant height $(11.92 \%)$, days to $50 \%$ flowering (13.77\%), number of tillers per hill (14.32\%), flag leaf length (17.94\%) and test weight (18.59\%). High for (above 20\%) number of spikelets per panicle $(23.67 \%)$ and number of panicles per hill (31.11\%). 
The PCV ranged from harvest index (5.29\%) to number of panicles per hill $(31.27 \%)$. The PCV estimates would show that the phenotypic variability was low for harvest index (5.29\%), Moderate for panicle length $(10.46 \%)$, flag leaf width $(11.34 \%)$, grain yield per hill (11.53\%), plant height (12.34\%), days to $50 \%$ flowering $(13.78 \%)$, biological yield $(14.49 \%)$, days to maturity $(15.54 \%)$, number of tillers per hill (17.52\%), test weight $(18.83 \%)$ and flag leaf length (18.92\%). High for number of panicles per hill (31.27\%).

In the present investigation, as expected, the PCV estimates were higher than the GCV estimates the variation due to environment as well as variation due to interactions. However, there was a close correspondence between the estimates of PCV and GCV for the characters $v i z$., days to $50 \%$ flowering, days to maturity, plant height, panicle length, flag leaf width, biological yield, test weight and grain yield per hill under study indicating the fact that these characters were less influenced by the environmental factors as evidenced from the less differences in magnitude of PCV and GCV.

In contrast, others characters, viz.,biological yield, days to maturity, number of tillers per hill and harvest index were highly influenced by environment as evidenced from high magnitudinal differences between the estimates of PCV and GCV. Hence selection for these characters sometimes may be misleading. These environmental factors could be due to heterogeneity in soil fertility status and other unpredictable factors (Reddy et al., 2012). The findings of (Falconer, 1960) are not only helpful in determining the heritable portion of variation. For this estimates of heritability of these traits are necessary. Similar pattern of PCV and GCV was reported by several workers for all of most of these characters (Dhurai et al., 2014, Rashmi et al., 2017, and Harsha et al., 2017). According to Burton and Devane (1953) heritability in broad sense is ratio bêtween genotypic variance to total variance.

Table.1 Analysis of variance for 13 characters of 25 rice genotypes during kharif-2018

\begin{tabular}{|c|c|c|c|}
\hline \multirow{2}{*}{ Characters } & \multicolumn{3}{|c|}{ Mean Sum of Squares } \\
\cline { 2 - 4 } & Replication & Treatments & Error \\
\hline Days to 50\% flowering & 0.013 & $\mathbf{( d f}=\mathbf{2 4})$ & $\mathbf{( d f = 4 8 )}$ \\
\hline Plant height & 2.271 & $577.564^{* *}$ & 0.305 \\
\hline Flag leaf length & 1.64 & $122.00^{* *}$ & 13.729 \\
\hline Flag leaf width & 0.005 & $0.086^{*}$ & 4.42 \\
\hline No of Tillers/hill & 1.281 & $12.245^{* *}$ & 0.002 \\
\hline No of Panicles/ hill & 0.410 & $12.249^{* *}$ & 1.742 \\
\hline Panicle length & 1.638 & $22.497^{* *}$ & 0.126 \\
\hline No of Spikelets/panicle & 1.960 & $7445.784^{* *}$ & 0.772 \\
\hline Days to maturity & 122.080 & $855.119^{* *}$ & 0.960 \\
\hline Biological yield & 98.314 & $206.566^{* *}$ & 73.511 \\
\hline Test weight & 1.960 & $51.708^{* *}$ & 0.460 \\
\hline Harvest Index & 4.029 & $15.152^{* *}$ & 2.192 \\
\hline Grain Yield/ Plant & 5.760 & $49.465^{* *}$ & 1.010 \\
\hline
\end{tabular}

** Significant at $1 \%$ level of significance, * Significant at $5 \%$ level of significance 
Table.2 Mean performance for 13 quantitative characters of 25 rice genotypes during kharif-2018

\begin{tabular}{|c|c|c|c|c|c|c|c|c|c|c|c|c|c|}
\hline Genotypes & $\begin{array}{c}\text { Days to } \\
50 \% \\
\text { flowering }\end{array}$ & $\begin{array}{c}\text { Plant } \\
\text { height } \\
\text { (cm) }\end{array}$ & $\begin{array}{c}\text { Flag leaf } \\
\text { length } \\
(\mathrm{cm})\end{array}$ & $\begin{array}{c}\text { Flag leaf } \\
\text { width } \\
(\mathrm{cm})\end{array}$ & $\begin{array}{c}\text { No of } \\
\text { Tillers/ } \\
\text { hill }\end{array}$ & $\begin{array}{c}\text { No of } \\
\text { Panicles/ } \\
\text { hill }\end{array}$ & $\begin{array}{c}\text { Panicle } \\
\text { length } \\
(\mathrm{cm})\end{array}$ & $\begin{array}{c}\text { No of } \\
\text { Spikelets/ } \\
\text { panicle }\end{array}$ & $\begin{array}{l}\text { Days to } \\
\text { maturity }\end{array}$ & $\begin{array}{l}\text { Biological } \\
\text { yield }(g)\end{array}$ & $\begin{array}{c}\text { Test } \\
\text { weight }(\mathrm{g})\end{array}$ & $\begin{array}{c}\text { Harvest } \\
\text { Index } \\
(\%)\end{array}$ & $\begin{array}{c}\text { Grain } \\
\text { Yield/ } \\
\text { hill (g) }\end{array}$ \\
\hline MTU - 1001 & 111.33 & 111.87 & 35.65 & 1.59 & 14.33 & 13.20 & 25.40 & 197.67 & 138.67 & 85.13 & 16.98 & 47.81 & 40.50 \\
\hline MTU - 1061 & 126.00 & 99.83 & 27.30 & 1.33 & 16.47 & 14.27 & 24.40 & 196.67 & 153.67 & 74.67 & 19.44 & 42.57 & 31.60 \\
\hline MTU - 1064 & 122.67 & 105.21 & 30.67 & 1.49 & 14.53 & 12.47 & 24.70 & 241.67 & 149.67 & 80.20 & 22.80 & 48.02 & 38.50 \\
\hline MTU - 1075 & 121.33 & 111.06 & 29.78 & 1.56 & 12.33 & 9.00 & 25.80 & 256.33 & 149.33 & 83.87 & 17.38 & 51.48 & 43.00 \\
\hline MTU - 1121 & 119.67 & 104.48 & 30.49 & 1.61 & 12.93 & 10.80 & 26.50 & 259.00 & 147.67 & 86.80 & 18.58 & 48.98 & 42.40 \\
\hline MTU - 7029 & 119.00 & 83.85 & 20.20 & 1.32 & 15.27 & 14.73 & 23.90 & 231.67 & 148.00 & 71.53 & 18.38 & 49.94 & 35.60 \\
\hline BPT - 3291 & 114.67 & 94.28 & 35.54 & 1.75 & 11.40 & 10.27 & 22.30 & 262.33 & 142.67 & 76.27 & 15.34 & 49.45 & 36.70 \\
\hline BPT - 5204 & 121.00 & 89.25 & 24.31 & 1.23 & 15.80 & 13.13 & 23.00 & 249.00 & 150.00 & 72.87 & 16.64 & 47.55 & 34.80 \\
\hline MTU - 1010 & 88.33 & 106.73 & 26.41 & 1.31 & 15.07 & 14.47 & 25.60 & 202.00 & 116.00 & 58.87 & 24.82 & 50.43 & 30.20 \\
\hline $\begin{array}{c}\text { HHZ3 - SAL6 - Y1 - } \\
\text { Y2 }\end{array}$ & 88.00 & 120.04 & 41.64 & 1.55 & 11.27 & 9.13 & 26.00 & 316.33 & 118.00 & 69.00 & 22.56 & 48.19 & 33.30 \\
\hline IR - 11A 257 & 95.33 & 129.13 & 40.04 & 1.41 & 13.40 & 10.33 & 34.10 & 187.00 & 124.33 & 79.80 & 26.50 & 49.73 & 38.70 \\
\hline IR - 10N 276 & 87.00 & 140.20 & 41.76 & 1.58 & 9.27 & 9.13 & 25.90 & 244.00 & 115.00 & 51.20 & 23.56 & 51.93 & 26.90 \\
\hline $\begin{array}{c}\text { HHZ4 - SAL } 12 \text { - LI1 } \\
\text { - LI2 }\end{array}$ & 86.00 & 125.87 & 37.90 & 1.51 & 11.67 & 10.60 & 29.30 & 171.67 & 116.00 & 67.27 & 22.76 & 46.31 & 30.70 \\
\hline PR - 133 & 94.67 & 110.10 & 37.87 & 1.79 & 9.67 & 7.67 & 24.80 & 200.67 & 122.67 & 70.47 & 30.86 & 49.27 & 34.80 \\
\hline IR - 11N - 187 & 98.33 & 127.50 & 48.03 & 1.39 & 12.20 & 10.07 & 29.50 & 239.00 & 127.33 & 82.47 & 26.55 & 48.56 & 40.20 \\
\hline IR - 118 - 304 & 94.67 & 126.30 & 33.57 & 1.54 & 12.47 & 11.40 & 31.60 & 217.33 & 123.67 & 71.93 & 25.22 & 50.38 & 35.90 \\
\hline SHIATS DHAN - 1 & 98.00 & 130.11 & 41.59 & 1.87 & 16.60 & 14.40 & 26.80 & 274.33 & 127.00 & 79.67 & 17.40 & 47.80 & 38.00 \\
\hline SHIATS DHAN - 2 & 93.67 & 126.81 & 40.45 & 1.50 & 13.40 & 10.33 & 27.90 & 147.33 & 121.67 & 80.47 & 26.23 & 47.72 & 38.40 \\
\hline SHIATS DHAN - 3 & 91.67 & 119.84 & 32.67 & 1.24 & 14.00 & 12.00 & 30.20 & 216.33 & 120.67 & 77.33 & 23.50 & 48.94 & 37.50 \\
\hline SHIATS DHAN - 4 & 105.00 & 128.70 & 38.55 & 1.68 & 12.40 & 10.27 & 26.50 & 212.33 & 134.00 & 77.53 & 16.60 & 46.77 & 36.00 \\
\hline SHIATS DHAN - 5 & 95.67 & 120.77 & 37.97 & 1.38 & 15.40 & 13.27 & 28.70 & 213.67 & 124.67 & 75.13 & 21.62 & 46.47 & 34.90 \\
\hline TP -30596 & 86.33 & 109.11 & 32.69 & 1.55 & 13.07 & 10.73 & 29.40 & 124.33 & 115.50 & 75.47 & 25.44 & 43.80 & 33.10 \\
\hline TP -30601 & 88.33 & 121.57 & 36.95 & 1.51 & 10.80 & 9.60 & 28.10 & 152.00 & 118.33 & 85.07 & 24.80 & 47.27 & 40.10 \\
\hline$T P-30603$ & 87.33 & 112.21 & 39.11 & 1.61 & 10.73 & 8.53 & 27.90 & 132.67 & 116.67 & 72.27 & 25.80 & 50.72 & 36.60 \\
\hline TP -30606 & 89.33 & 121.56 & 31.41 & 1.72 & 12.27 & 10.93 & 28.40 & 117.00 & 119.33 & 65.87 & 26.20 & 45.10 & 29.60 \\
\hline Mean & 100.93 & 115.06 & 34.90 & 1.52 & 13.07 & 11.23 & 27.07 & 210.49 & 129.62 & 74.85 & 22.24 & 48.21 & 35.92 \\
\hline CD5\% & 0.91 & 6.08 & 3.45 & 0.07 & 2.17 & 0.58335 & 1.44 & 1.61 & 22.18 & 14.04 & 1.11 & 2.43 & 1.65 \\
\hline Max & 126.00 & 140.20 & 48.03 & 1.87 & 16.60 & 14.73 & 34.10 & 316.33 & 153.67 & 86.80 & 30.86 & 51.93 & 43.00 \\
\hline Min & 86.00 & 83.85 & 20.20 & 1.23 & 9.27 & 7.67 & 22.30 & 117.00 & 115.00 & 51.20 & 15.34 & 42.57 & 26.90 \\
\hline
\end{tabular}


Table.3 Estimation of genetic parameters for grain yield and other components in rice

\begin{tabular}{|c|c|c|c|c|c|c|c|}
\hline Characters & $\mathbf{V g}$ & $\mathbf{V p}$ & $\mathbf{G C V}$ & $\mathbf{P C V}$ & Heritability & GA & $\begin{array}{c}\text { GA AS } \\
\text { \% Mean }\end{array}$ \\
\hline $\begin{array}{c}\text { Days to 50\% } \\
\text { flowering }\end{array}$ & 193.09 & 193.39 & 13.77 & 13.78 & 99.84 & 28.60 & 28.34 \\
\hline Plant height & 187.94 & 201.67 & 11.92 & 12.34 & 93.19 & 27.26 & 23.70 \\
\hline Flag leaf length & 39.19 & 43.61 & 17.94 & 18.92 & 89.86 & 12.22 & 35.03 \\
\hline Flag leaf width & 0.03 & 0.03 & 10.98 & 11.34 & 93.66 & 0.33 & 21.88 \\
\hline No of Tillers/hill & 3.50 & 5.24 & 14.32 & 17.52 & 66.78 & 3.15 & 24.10 \\
\hline No of Panicles/ hill & 12.21 & 12.33 & 31.11 & 31.28 & 98.98 & 7.16 & 63.77 \\
\hline Panicle length & 7.24 & 8.01 & 9.94 & 10.46 & 90.37 & 5.27 & 19.47 \\
\hline $\begin{array}{c}\text { No of } \\
\text { Spikelets/panicle }\end{array}$ & 2481.61 & 2482.57 & 23.67 & 23.67 & 99.96 & 102.60 & 48.74 \\
\hline Days to maturity & 224.20 & 406.71 & 11.53 & 15.54 & 55.13 & 22.90 & 17.64 \\
\hline Biological yield & 44.46 & 117.65 & 8.91 & 14.49 & 37.79 & 8.44 & 11.28 \\
\hline Test weight & 17.08 & 17.54 & 18.59 & 18.83 & 97.38 & 8.40 & 37.78 \\
\hline Harvest Index & 4.32 & 6.51 & 4.31 & 5.29 & 66.34 & 3.49 & 7.23 \\
\hline Grain Yield/ hill & 16.15 & 17.16 & 11.19 & 11.53 & 94.11 & 8.03 & 22.36 \\
\hline
\end{tabular}

$\mathrm{Vg}$ = genotypic variance, $\mathrm{Vp}=$ phenotypic variance, $\mathrm{GCV}=$ Genotypic coefficient of variation, $\mathrm{PCV}=$ Phenotypic coefficient of variation, $\mathrm{GA}=$ Genetic advance

The estimates of genotypic coefficient of variation $(\mathrm{GCV})$ reflect the total amount of genotypic variability present in the material. However, the proportion of this genotypic variability which is transmitted from parents to offspring is reflected by heritability. Broad sense heritability determines the efficiency with which we can utilize the genotypic variability in breeding programme. The genotypic variance and its components are influenced by the gene frequencies of genes differ from one population to another, estimates of heritability also vary from one population to another for a given character. The range of heritability was considered as low $(<30 \%)$, medium $(30-60 \%)$ and high (>60\%) as proposed by Johnson et al., (1955). The estimates of heritability from present investigation are presented in Table 3.

In the present study, the heritability in broad sense (h2) ranges from biological yield $(37.79 \%)$ to number of spikelets per panicle (99.96\%). High estimates of heritability (above 60\%) recorded for harvest index $(66.34 \%)$, number of tillers per hill $(66.78 \%)$, flag leaf length $(89.86 \%)$, panicle length (90.37\%), plant height (93.19\%), flag leaf width (93.66\%), grain yield per hill $(94.11 \%)$, test weight $(97.38 \%)$, number of panicles per hill $(98.97 \%)$, number of spikelets per panicle $(99.96 \%)$ and days to $50 \%$ flowering (99.84\%). While moderate estimate of heritability for (30-60\%) biological yield $(37.79 \%)$ and days to maturity $(55.13 \%)$. None of the characters showed low estimates of heritability (below 10\%). It showed that the phenotypic variability of none characters had greater share of environmental.

The estimates of heritability are more advantageous where expressed in terms of genetic advance. Johnson et al., (1955) suggested that without genetic advance the estimates of heritability will not be of practical value and emphasized the concurrent use of genetic advance along with heritability. Genetic advance as percent mean was low 
(below 10\%) for harvest index (7.23\%) and moderate (10-20\%) for biological yield (11.28\%), days to maturity (17.64\%) and panicle length (19.47\%). While high genetic advance as percent mean (above 20\%) recorded for flag leaf width $(21.88 \%)$, grain yield per hill (22.36\%), plant height $(23.70 \%)$, number of tillers per hill $(24.10 \%)$, days to $50 \%$ flowering $(28.34 \%)$, flag leaf length (35.03\%), test weight (37.78\%), number of spikelets per panicle $(48.74 \%)$ and number of panicles per hill (63.76\%).

Most of the characters showed high heritability coupled with high genetic advance as percent mean was observed for flag leaf width, grain yield per hill, plant height, number of tillers per hill, days to $50 \%$ flowering, flag leaf length, test weight, number of spikelets per panicle and number of panicles per hill. Whereas high heritability coupled with moderate genetic advance as percent mean was observed for biological yield, days to maturity and panicle length indicating that this charater seems to be heritable and can be improved by selection. These findings were in accordance with Deepa et al., (2006), Prajapathi et al., (2011) and Sandeep et al., 2018.

Moderate heritability coupled with high genetic advance as percent mean was observed for biological yield, while high heritability coupled with low genetic advance as percent mean was observed for number of panicles per hill which indicated the moderate influence of environment and selection would be ineffective.

From the present investigation it is concluded that among 25 genotypes of rice on the bases of mean performance MTU-1010 (6.8 t/ha) was found to be superior in grain yield over the check followed by MTU-1121 (6.2 t/ha), SHIATS DHAN-1 (6.0 t/ha) and MTU-1075 (5.9 t/ha) showed 1-1.2 t/ha over the check and these genotypes showed high variability for all 13 quantitative parameters taken in the present study.

High to moderate estimates of GCV and PCV were recorded for number of panicles per hill, number of spikelets per panicle, test weight, flag leaf length, days to $50 \%$ flowering, plant height and grain yield per hill. High estimates of heritability coupled with high values of genetic advance as percent mean was observed for characters number of spikelets per panicle, days to $50 \%$ flowering, number of panicles per hill and test weight respectively suggesting that there was preponderance in gene action.

\section{References}

Allard, R. W. 1960. Principles of Plant Breeding. John Wiley and Sons Inc. New York. pp 485.

Burton, G.W. (1952). Quantitative inheritance of grasses. Proc. $6^{\text {th }}$ International Grassland Congress. 1: 277-283.

Burton, G.W. and Devane. (1953). Estimation of heritability in tall fescue Festula arundnacea from replicated clonal material. Agronomy Journal, 45: 478481.

Dhurai, S.Y., Bhati, P.K. and Saroj, S.K. (2014). Studies on Genetic Variability For Yield and Quality Characters In Rice (Oryza sativa L.) Under Integrated.

Falconer, D. S. (1960). Introduction to quantitative genetics Edinburgen and London: Aliver and Bodyd.

Garris A. J., Tai T. H., Coburn J., Kresovich S and Mc Couch S. Genetic Structure and diversity in Oryza sativa Genetics. 2005; 169: 1631-1638.

Harsha, Deo, Indra., Kumar, sudhir and Talha, Mohammed (2017). Assessment of Genetic variability and character association studies in rice genotypes 
(Oryza sativa L.). International Journal of Current Microbiology and Applied Sciences. 6(10); 2865-2869.

Hossain S., maksudu H.M. D and Jamilur R. J. Genetic variability, Correlation and Path Coefficient Analysis of Morphological traits in some Extinct Local Aman Rice (Oryza sativa L.). Journal of Rice Research. 2015; 3.

Islam. M. J., Raffi. S. A., Hossain. M A. and Hanson. A. K. (2015). Analysis of genetic variability, heritability and genetic advance for yield and yield associated traits in some promising advanced lines of rice (Oryza sativa L.). Progressive Agriculture. 26(1): 26-31.

Johnson, H.W., Robinson, H.F and Comstock, R.E. (1955). Estimates of genetic and environment variability in soyabean. Agronomy Journal, 47: 314-318.

Khush G. S and Virk P. S. Rice breeding: Achievement and future strategies. Crop Improvement. 2000; 27: 115-144.

Muhammad, T., Dera, W. and Ahmed Z. (2002). Genetic Variability of different plant and yield characters in rice. Sarha Journal of Agriculture, 18 (2): 207-210.

Panse, V. G and Sukhatne, P. V. (1961). Statistical methods for agricultural workers $2^{\text {nd }} E d n$ ICAR, New Delhi ;P: 361.

Prajapathi, M.K., Singth, C. M., Suresh B. G., Lavanya, G. R and Jadhav. P. (2011). genetic parameters for grain yield and its component characters in rice (Oryza sativa L.). Electronic Journal of Plant Breeding. 2(2): 235-238.

Rashmi, Deep., Singh, Pawan Kumar., Loitongbam, Bapsila, (2017). Genetic variability study for yield and yield components in rice. International Journal of Agriculture, Environment and Biotechnology 10(2): 171-176, April 2017.

Reddy, G. E., Suresh B. G., Sravan, T and Reddy, A. (2013). Interrelationship and cause effect analysis if rice genotypes in North East Plain Zone. The Bioscan. 8(4): 1141-1144.

Sandeep. S, Sujatha. M, Subbarao. LV. and Neeraja. C. N., (2018). Genetic variability, heritability and genetic advance studies in rice (Oryza sativa L.). International Journal of Current Microbiology and Applied Sciences. 7(12): 3719-3727.

Senapati, B.K and Kumar, A. (2015). Genetic assessment of some phenotypic variants of rice (Oryza Sativa L.) for quantitative characters under the Gangatic plains of West Bengal. Academic Journal. 4 (3): 187-201.

Smith., Bruce D. The Emergence of Agriculture. Scientific American Library A Division of HPHLP, New York, ISBN 0-7167-6030-4. 1998.

\section{How to cite this article:}

Sirigadi Rajesh, K. Chaithanya, J. Sajeev, B. Jalandhar Ram and Suresh B. G. 2019. Genetic Variability, Heritability and Genetic Advance studies in Quantitataive Traits in Rice (Oryza sativa L.). Int.J.Curr.Microbiol.App.Sci. 8(08): 2220-2226.

doi: https://doi.org/10.20546/ijcmas.2019.808.257 